Jon Magne Vestøl

Department of Teacher Education and School Research

University of Oslo

Email:j.m.vestol@ils.uio.no

\title{
Design, Integration, and Quality. Teacher Education from the Perspective of ProTed, a Norwegian Centre of Excellence in Education
}

\begin{abstract}
Drawing on the developmental work of ProTed, a Norwegian Centre of Excellence in Education, this article contributes to the understanding of three concepts of central importance for the construction, development and evaluation of teacher education. Based on material from theory seminars, structured reports and other data from ProTed's development projects, the article presents an understanding of the concepts design, integration and quality. Design is presented as an activity, a dynamic competence development where teaching is transformed into learning. Knowledge integration is understood as a core element of this design, and different forms and aspects of integration are explored. An understanding of quality evaluation is presented that emphasises performative and transformative aspects of the competence development that is generated through the design activity.
\end{abstract}

Keywords: teacher education, design, integration, quality, ProTed

\section{Sammendrag}

Artikkelen tar utgangspunkt i utviklingsarbeid i ProTed, Senter for fremragende larerutdanning, og bidrar til å belyse tre begreper av sentral betydning for utforming, utvikling og evaluering av lererutdanning. Basert på teoriseminarer, strukturerte rapporter og annet empirisk materiale fra ProTeds utviklingsprosjekter presenterer artikkelen tre hovedbegrep: design, integrasjon og kvalitet. Design presenteres som en virksomhet, en dynamisk kompetanseutvikling hvor undervisning transformeres til laring. Kunnskapsintegrasjon forstås som et kjerne-element $i$ et slikt design, og artikkelen utforsker ulike former for integrasjon. Artikkelen presenterer også et perspektiv på kvalitetsvurdering som legger vekt på performative og transformative aspekt ved den kompetanseutviklingen som genereres gjennom designvirksomheten.

Nøkkelord: lærerutdanning, design, integrasjon, kvalitet, ProTed 


\section{Introduction}

A recent meta-study of research on teacher education (Cochran-Smith \& Villegas, 2015; Cochran-Smith et al., 2015) highlights three major "trends": attention to quality, changing conceptions of learning and knowledge, and increasingly diverse student populations (Cochran-Smith \& Villegas, 2015).

Addressing some issues related to two of these trends, this article deals with issues of teacher education design with a particular focus on knowledge integration and quality evaluation. Unlike the international meta-study, this article addresses a national context, drawing on the work of the Norwegian Centre for Professional Learning in Teacher Education (ProTed). The article demonstrates how a conceptual framework for addressing and understanding teacher education has been developed through the work of this centre of excellence in education. While the conceptual framework has been developed under specific contextual premises in cooperation between the University of Tromsø (UiT) and the University of Oslo (UiO), this article also makes an effort to discuss the relevance of the framework in light of perspectives from international research on teacher education.

As already indicated, the scope of the article is thematic: to present a theoretically and empirically informed conceptual framework for teacher education that is developed by the ProTed centre with an emphasis on three core concepts, namely design, integration and quality. After a brief description of the ProTed centre, the article gives a short introduction to the conceptual framework before it proceeds into more detailed presentations of the three concepts and a final discussion.

\section{Background: The ProTed Centre}

ProTed was established in 2012 as the first Norwegian Centre of Excellence in Education. Constructed as a joint venture between the teacher training programmes at the University of Oslo (UiO) and the University of Tromsø (UiT), the central objective of ProTed is "to develop integrated teacher education programmes”, implying "a coherent study design where scientific subjects, school subjects, pedagogy, subject didactics, theory, and practice constitute a whole as a basis for teaching as a profession” (ProTed, 2015).

The work has been structured around five developmental areas or "work packages" (WP1-5), including more than thirty developmental projects. The first four work packages are as follows:

- WP1 (Teaching subjects) investigates ways of teaching, disseminating and researching within subject disciplines. 
- WP2 (University schools and professional practice) develops structures and environments for dialogue and cooperation between universities and the field of practice.

- WP3 (Digital learning environments) develops the understanding of and use of digital tools in teacher education and in classrooms.

- WP4 (Educational leadership and staff competence development) develops organisational models and structures for teacher education.

The projects of WP1-4 are related to the five-year teacher education programmes (MA programmes) at UiT and UiO. While some projects are fully implemented in regular courses, others are pilots, and some are under development. Some projects aim at developing experience and understanding of an issue or tool, some aim at instantiating specific means of teaching and learning, while some aim at developing structures and organisations. Although many projects are still developing, some reports and studies have been published (Bakken \& Sollid, 2013; ProTed, 2014; Vestøl, 2014; Vestøl, Jakhelln, \& Lund, 2015).

To develop more overarching perspectives based on the work in these developmental areas, WP5 was established, focusing on issues of design and quality evaluations. The conceptual framework that is presented below has been developed through the work of this WP5.

\section{The conceptual framework: Theoretical and empirical basis}

Although the work of the ProTed Centre is still in progress, contours of a conceptual framework have emerged through theory seminars as well as syntheses of project reports and analyses of empirical data. In this section, three main concepts of this framework, i.e. design, integration and quality, are briefly introduced and tentatively related to perspectives from international research.

\section{Design}

The understanding of the design concept in ProTed has been developed through several theory workshops with participators from WP1-5 (2013-2015), and results from this development have been partly addressed in a previous publication (Vestøl et al., 2015). The present article has also drawn on aggregated summaries from structured reports from 33 ProTed projects to develop a synthesis between theoretical and more empirical aspects regarding the understanding of design, as is shown below (Figure 1).

Generally, the term design has been used to describe various approaches to education (for brief summaries, see Hauge, 2014; Lund \& Hauge, 2011). The term is also used in more loosely defined ways, as when the term programme design is used as a label for shaping the overall structure of education (DarlingHammond \& Hammerness, 2005). In ProTed, a specific use of the design 
concept has been developed, drawing on work by researchers at $\mathrm{UiO}$ inspired by activity theory (Hauge, 2014; Hauge, Lund, \& Vestøl, 2007) and including central aspects of the action research tradition of UiT (Carr \& Kemmis, 1986; Tiller, 2006). Although activity theory and action research represent independent theoretical developments, ProTed has found the perspectives to be compatible since they both emphasise processes of change and development (cfr. Postholm \& Jacobsen, 2011).

Drawing on the socioculturally embedded Cultural-Historical Activity Theory (CHAT), the design perspective emphasises teaching and learning as object-oriented processes mediated through cultural tools (Daniels, 2001; Engeström, 1987; Vygotsky, 1978), within collectively organised activities (Hauge, 2014; Hauge et al., 2007; Lund \& Hauge, 2011). Action research has contributed an emphasis on activity as systematic development and change and active participation (Carr \& Kemmis, 1986; Tiller, 2006). This design perspective is seen as an analytical tool for examining and transforming vital elements and processes of ongoing teacher education activity within ProTed.

\section{Integration (and coherence)}

The understanding of the concept integration in this article is partly informed by previously published analyses of student teachers' exam texts and related group interviews with student teachers and staff members at UiO (Vestøl, 2014). In the present article, this concept is related to National Curriculum Regulations (Figure 2) and the overall design framework. It is also discussed in light of international research on coherence.

Integration and coherence are used as closely connected concepts in the description of ProTed's objectives (ProTed, 2015), referring to the way teacher education programmes try to facilitate productive intersections between fields of knowledge such as scientific content knowledge, pedagogical knowledge and practical knowledge.

According to Basil Bernstein's work on curriculum integration (Bernstein, 1975, p. 80), integration takes place when various knowledge contents "stand in an open relation to each other" and are "subordinate to some idea which reduces their isolation from each other". In ProTed, efforts have been made to address student teachers' integration of knowledge in light of Bernstein's understanding.

In international research literature on teacher education, the concept of integration tends to be used in loosely defined ways, while the related concept of coherence has been more precisely developed. Since ProTed has addressed both integration and coherence in its objectives, the international research on coherence is of relevance to the centre's framework development. Coherence has been addressed in particular by researchers such as Pamela Grossmann and Karen Hammerness (Grossmann, Hammerness, McDonald, \& Ronfeldt, 2008). In a recent study on Norwegian teacher education, Hammerness (2013) emphasises that powerful teacher education programmes share a clear vision; a 
coherent, reflective and clear understanding; and a core curriculum highly connected to teaching practice. According to Hammerness, while Norwegian teacher education programmes show weak coherence, the Stanford Teacher Education Program (STEP) has a conceptual and structural coherence and vision (Hammerness, 2006).

Hammerness makes a distinction between conceptual coherence in terms of ideas or visions and structural coherence in terms of logistics or designs, and emphasises coherence as a qualitative "process of adjustment" (Hammerness, 2006, p. 1262). Grossmann, Hammerness and their co-authors (Grossmann et al., 2008) understand coherence as a sharing of "central ideas regarding teaching and learning" and an organising of "learning opportunities" towards such ideas "both conceptually and logistically". Coherence is not to be reduced to "mere consistency", but should be understood as an "alignment of ideas and learning opportunities” (Grossmann et al., 2008, p. 274).

Other researchers such as Buchmann and Floden (1992) have strongly emphasised the difference between consistency as logical relations without contradictions, and coherence, which in their opinion "allows for many kinds of connectedness, encompassing logic but also associations of ideas and feelings, intimations of resemblance, conflicts and tensions” (Buchmann \& Floden, 1992, p. 4) They underscore the need for students to experience the struggle to make sense of discordances and discrepancies and that an education that is screened through some neat integrative framework may deprive students from important aspects of thinking and learning.

\section{Quality}

ProTed's emerging conceptual framework also includes perspectives on how one can describe and evaluate the quality of a teacher education design and the knowledge integration taking place in the education. The concept of quality has been tentatively discussed in a previous publication based on examples from student teachers' papers and internship practice (Vestøl, 2015), and in the present article, this concept is related more explicitly to the design framework (Figure 3).

Quality in higher education has been addressed from varying angles, for instance as exception, perfection, standardisation, adjustment for purpose, effectiveness and transformation (Aamodt, Hovdhaugen, \& Prøitz, 2014; DahlerLarsen, 2013; Harvey \& Green, 1993; Stensaker, 2013; Wittek \& Kvernbekk, 2011). It has also been pointed out how tensions may exist between notions of quality, for instance between a result-oriented understanding among politicians and the process-oriented approach in academic institutions (Stensaker, 2013).

Quality is often addressed and operationalised through the use of indicators that act as formal references to aspects not directly observable and as means of evaluation on both international, national and institutional levels (Erstad, 2009; Kikis, Scheuermann, \& Villalba, 2009; Pelgrum, 2009). Indicators in teacher 
education can be quantitative as in grades, intake and graduation numbers. While quantitative indicators may lack contextual information (Pelgrum, 2009), evaluations of a more qualitative nature may be systematised and regarded as qualitative indicators (Bastia, 2000) to include factual information and opinions of the persons involved. Different quality descriptions and indicators will respond to different aspects of teacher education, and it will therefore be of importance to interrelate the development of design and the development of quality descriptions.

After this brief overview, the three concepts are described in more detail in the following three sections.

\section{Design}

Drawing on sociocultural embedded activity theory, the design perspective developed in ProTed understands teacher education as an activity where teacher competence is processed as an educational object. This is a process that is mediated through the use of a range of cultural tools. Emphasis is placed on the interaction between a design for teaching developed by teacher educators and a design for learning, which is developed by student teachers as they transform elements presented by teacher educators into elements of their own learning process. Moreover, drawing on action research, there is an emphasis on design as systematic development and change ('improvement') as well as active participation ('involvement') (Carr \& Kemmis, 1986; Tiller, 2006).

Figure 1 displays how the above-mentioned design elements emerge in light of structured reports from the 33 ProTed sub-projects. The figure is organised around a Vygotskian triangle of mediated action (Hauge et al., 2007; Vygotsky, 1978) to indicate how the participants (subjects) draw on cultural resources (tools) to process a teacher education (object) with a particular focus. The double shape of the triangle symbolises how student teachers transform the teacher educators' design into a learning design through their appropriation and mastery of knowledge and skills.

Activity: As Figure 1 shows, design is understood as a dynamic activity between three basic elements: subject, object and mediating tools. As indicated by the horizontal bottom line, the activity is also conditioned by procedures, structures of participation and community aspects. An activity is thus understood as organised coordination and cooperation of individual acts that contribute to a shared direction and common purpose. In ProTed, the overall activity is a complex entity involving two teacher education institutions and a range of subprojects that are activities in their own respect but also contribute to an activity centred in the work of the ProTed leadership group.

Subject: As indicated in the left-hand part of Figure 1, the ProTed subject includes a variety of participants, such as university and school staff members, 
student teachers, pupils and others. Three different kinds of role structures have been identified. The dominating trait is a subject role acted out by academic staff members who develop and implement new ways of dealing with central aspects of teacher education and who make efforts to include other groups of actors, such as student teachers and supervisors.

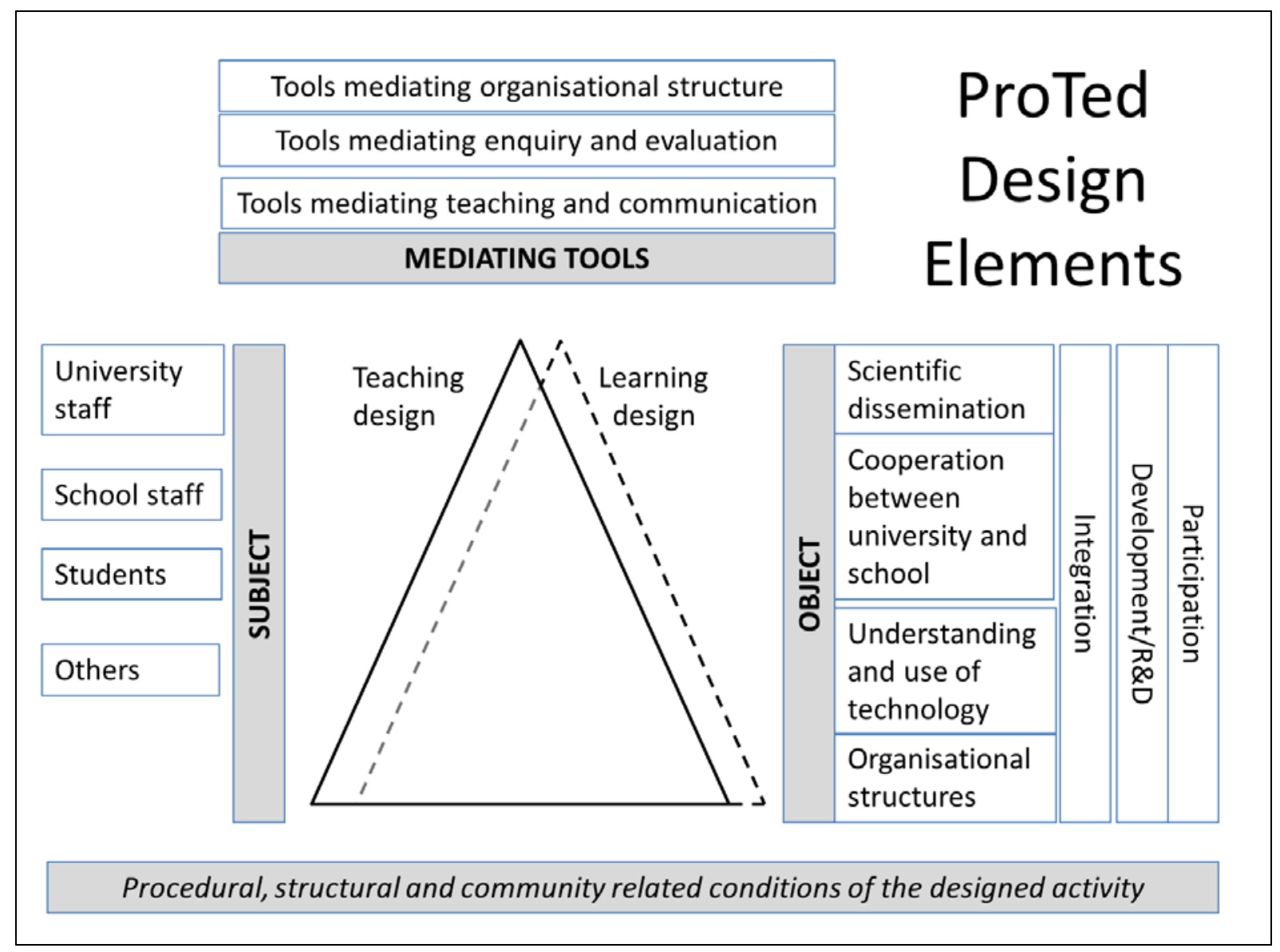

Figure 1. Design elements across ProTed sub-projects

Another trait is found particularly in WP2 projects, where structures are developed for mutual exchange and cooperation between different groups of participants. One example is so-called "dialogue seminars", developed at UiT and implemented at UiO. These include student teachers, teacher educators from the university and supervisors from the practice schools in mutual dialogic reflections about school-related topics.

A third trait related to the subject element is found in projects where courses and assignments are developed that invite student teachers to be in charge of their own knowledge development. Examples of such structures of participation are when student teachers run their research projects or take over the administration and teaching of schools for a limited period.

Mediating tools: In the projects, the participants (subject) make use of a range of mediating tools or artefacts to develop the organisational structures, 
knowledge and competence included in the object. As indicated in the upper part of Figure 1, such tools may have the shape of organisational structures and means of enquiry and evaluation as well as means of teaching and communication.

While some of the tools applied in the ProTed projects are well known to teacher education, others are new and freshly developed contributions. For instance, in the dialogue seminars mentioned above, specific procedures for structured dialogue have been introduced to facilitate the processing of shared knowledge. Another example is a digital exam at UiO and UiT in which a digital video case from a classroom situation has been developed in combination with a structured procedural framework to stimulate concentrated knowledge integration based on student teachers' previous preparations.

Object: As indicated in the right-hand part of Figure 1, the range of tools applied in ProTed serve to mediate a composite and complex object. This object - not unexpectedly - involves the main foci of the four developmental areas of ProTed: 1) the development of ways to disseminate and communicate scientific knowledge, 2) the development of structures and means to facilitate cooperation between universities and schools, 3) the development of the understanding and pedagogical use of technology, and 4) the development of organisational and pedagogical structures that strengthen the integration and application of knowledge among staff and student teachers. While each of these four foci characterises one developmental area and its associated projects in particular, the foci also tend to interact and merge in different ways across areas and projects.

In addition to the four domain-specific foci, distinct traits also emerge across the range of ProTed projects, as indicated in the columns to the far right in Figure 1. There is a general focus on development and new ways of integration and on new structures and arenas of participation. These three aspects interact in varying ways with each other and with the four foci described above, creating complex and dynamic intersections. While integration is investigated in a separate section, descriptions of the development and participation aspects are given briefly here.

Development: The development aspects in Figure 1 include the development of knowledge, structures and tools. There is a genuine connection between development and research (R\&D focus), although the presence and strength of this connection varies. In some projects, development is followed by researchbased evaluations, while other projects plan on having such evaluations. Some projects have a more specific focus on the development of R\&D competence among student teachers. While there seems to be a general focus on the importance of research-based development, an $R \& D$ focus as an overall approach and perspective still remains to be developed and implemented.

Participation: A variety of participative aspects are also found. Some projects are restricted to the development of knowledge among staff members, while other projects give the student teachers a major role in competence and 
knowledge development through research or investigation. Of particular interest are university school projects within WP2, where there is an emphasis on the development of structures and arenas for the joint participation of academic staff members, supervisors, student teachers and others. The emphasis on participation is particularly strong in some of the projects initiated by UiT, partly due to the focus on participatory action research at this institution. As a result, participation is included as part of the object in the ProTed notion of design, indicating the importance of participation in the design models to be developed.

Teaching and learning design: Patterns of participation influence the relationship between teaching and learning design, illustrated by the triangles at the centre of Figure 1. Some projects primarily focus on design for teaching, as their main effort is to develop basic structures and competence among staff members that will be implemented in a teaching design (and eventually be taken further by student teachers into a learning design). Other projects focus on the design for learning as they are facilitating and framing learning processes that are basically driven by the student teachers themselves. Still other projects represent a balanced interaction between the full framed teaching design developed by staff members and learning designs that unfold when student teachers engage with and transform the object and the tools presented in the teaching design. The emphasis on the teaching and learning parts of the design may also change through different phases or stages of a single project.

\section{Integration}

As indicated in Figure 1, integration is one among several dimensions that are found across a broader range of development projects in ProTed. A comparative reading of reports from ProTed's development projects identified aspects of integration that were visible to a varying extent across the range of projects:

- Organisation aspect of integration: Economic and social structures and infrastructures that serve as frameworks for cooperation between actors across contexts and knowledge domains, physically, virtually and mentally.

- Process aspect of integration: Modes of technical operation, modes of conceptual transformation and application and modes of personal transformation.

- Substance aspect of integration: Materially displayed connections between knowledge elements, knowledge domains and knowledge structures, both academic and practical.

As indicated in all three bullet points, a search for interaction between knowledge domains, concepts and knowledge structures has a central position across 
the ProTed projects. The bullet points above also show that there are close connections between the integration of knowledge domains and the economic, social, technical and organisational structures and conditions that facilitate (or hinder) such integration. Read in light of the definition by Bernstein referred to previously, integration thus implies that knowledge domains, as well as teaching and learning arenas, structures and participants are brought into a relationship that is coordinated by some overarching idea, principle or purpose.

As previously described (Vestøl, 2014), knowledge integration has been investigated more in detail through analyses of student teachers' exam papers from a digital home exam at $\mathrm{UiO}$ in 2013. The exam design focused on the student teachers' integration of knowledge, but gave the student teachers the intended freedom to explore a video case and choose a topic of discussion, which they then elaborated on, drawing on varying sources of knowledge, including their scientific subject and pedagogy as well as practical knowledge acquired through internship periods.

Analyses have shown (Vestøl, 2014) how the knowledge integration that was suggested in the exam's teaching design was realised by the student teachers in several distinct forms. Some student teachers based their knowledge integration on a concept or central issue from their scientific subject, e.g. history or social studies, which they subsequently elaborated upon in light of pedagogical concepts and practical knowledge. For instance, one student teacher investigated how the teaching of historical conscience might be related to theories of learning. Other student teachers based their knowledge integration on a concept or issue from pedagogy, which they then related to a topic from the scientific subject or school subject and to practical knowledge. For instance, a student teacher investigated issues of class discussions and class management, and related these issues to the social science topic of democratic citizenship.

While these ways of knowledge integration were based on well-defined concepts or topics, other student teachers undertook knowledge integration of a more exploratory character. For instance, some student teachers investigated an observed phenomenon of educational practice (from the video case), which they sought to clarify by using pedagogical concepts and by linking these to knowledge from the school subject or scientific subject. Others undertook an exploration of a concept or issue that was of high relevance to the school subject but that was not particularly well developed in the study literature. For instance, one student teacher sought to clarify the meaning and importance of the concept of 'dialogue' in religious and moral education by relating it tentatively to the scientific subject, pedagogy and practical knowledge.

This demonstrates how the exam design gave an opportunity for the students to transform the teaching design into a variety of learning designs where the object (integration) was developed in diverse ways and directions. In this way, the student teachers added considerably to the development of the design. Moreover, by demonstrating different forms of knowledge integration, 
they also strengthened ProTed's understanding of how a particular form of integration may respond to a particular demand in a classroom situation, and how student teachers may benefit from a knowledge and mastery of several integration forms.

The aspects and forms of integration described above suggest that integration may be regarded as a central dimension in the design of teacher education. As has been argued in a previous publication (Vestøl, 2014), this is in line with the descriptions of competence aims in the National Curriculum Regulations for Norwegian teacher education (KD, 2010, 2013), where knowledge integration constitutes the central dimension or nucleus of the competence descriptions. These competence descriptions are typically organised into three levels or groups of aims labelled as 'knowledge', 'skills', and 'general competence'. In light of Engeström's perspectives on learning (1987), these groups of aims may be interpreted as a three-levelled or three-dimensional structure of learning, as illustrated in Figure 2.

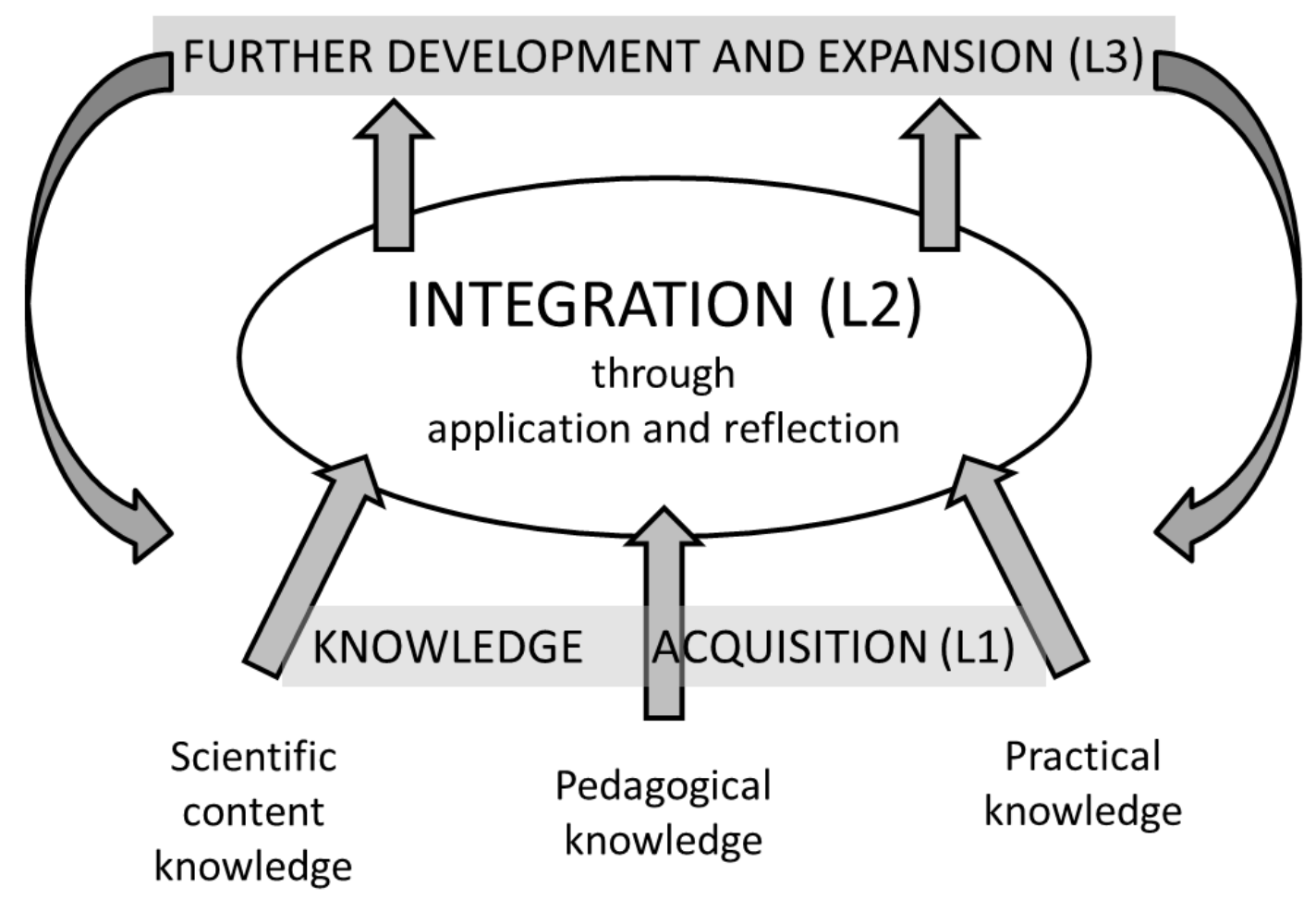

Figure 2. Levels or dimensions of competence in National Curriculum Regulations for teacher education

The aims addressing 'knowledge' indicate how student teachers acquire their knowledge from a range of fields: scientific content, pedagogy and practice or teaching experience (L1). Aims that address the development of 'skills' indicate the integration of knowledge elements and knowledge structures through critical reflection and the application of knowledge in their classroom teaching (L2). A 
third level or dimension (L3) is added through the competence aims that address 'general competence' by emphasising the capacity for further development and expansion to cope with new situations and challenges.

As indicated in Figure 2, the processes of application and reflection (L2) serve to integrate fields and elements of knowledge and also serve as a basis for the further development and expansion of the student teacher's integrated and applied knowledge (L3). Although processes of further development and expansion may belong to a more advanced phase of teachers' professional development, even student teachers are supposed to gain some competence related to these aspects.

To sum up, the presentation in this section indicates that knowledge integration plays a central role in the development of the student teachers' competence, indicating that such integration may serve as a nucleus in a teacher education design.

The presentation also shows that knowledge integration may have diverse forms and that the design should give student teachers opportunities to explore and develop a mastery of a wide range of integration forms in order to be equipped to respond to various classroom situations.

Moreover, it is demonstrated that knowledge integration involves the interrelationship of several factors, including organisation, process and substance. While the organisation and substance aspects have material manifestations that are more easily identified and addressed, the process aspects may be harder to identify and describe. This poses some challenges for the construction of a teacher education design and for the quality evaluation of a design, as is addressed in the following section.

\section{Quality}

As described previously, quality evaluations can be undertaken from a variety of perspectives and positions. Therefore, the understanding of quality in light of all the projects and design elements in ProTed may be both multi-faceted and complex. While one ProTed project (WP4) has an explicit focus on the development of quality systems in the teacher education at UiO, most projects address quality aspects more indirectly through processes of evaluation. To disclose elements of quality, one may search for its aspects drawing on the design framework presented in Figure 1, as tentatively sketched in Figure 3 below.

The figure demonstrates how the quality of the ProTed design may be related to the elements of the design as such, e.g. the tools (frame 2), as well as to the ways in which these elements interact, e.g. the interaction between teaching and learning designs (frame 3). The figure also addresses the relationship between academic and practical aspects of quality (frame I) and the quality of knowledge 
transformation (frame II). To explore these quality aspects in more detail, I address the frames contained in Figure 3.

\section{Quality aspects}

1

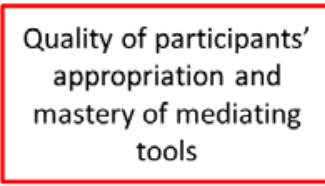

2 Quality of mediating ability of tools

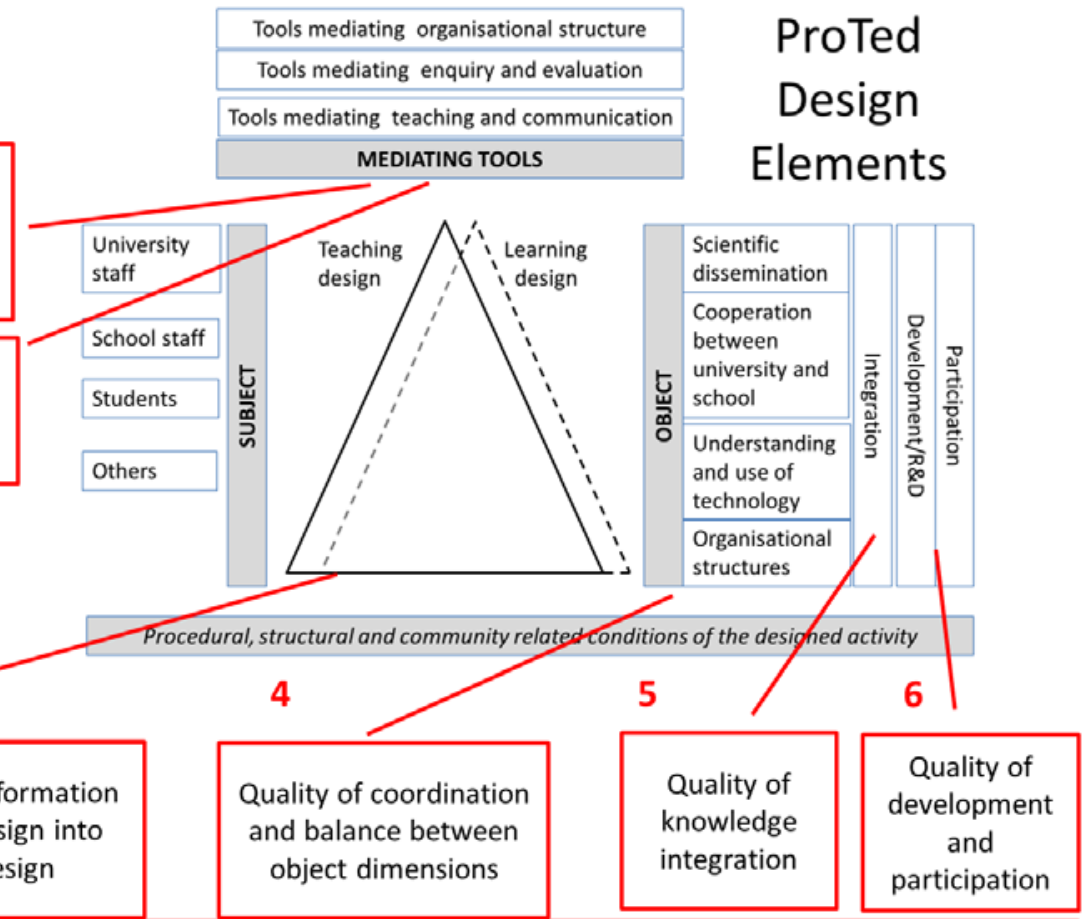

Degree of balanced and explicit relationship between academic and practical forms of quality

II

Degree of emphasis on transformative \& performative quality aspects

Figure 3. Tentative sketch of quality aspects of the ProTed design

Frames 1 and 2: As indicated in frames 1 and 2, aspects of quality relate to participants' mastery of cultural tools and the mediating force of these tools. For instance, the digital exam, along with other ProTed projects, introduce the student teachers to tools of observation and reflection. The quality of these tools and the manners in which they are used, contribute to the quality of the object development.

Frames 3 and 5: Traditionally, quality aspects of teacher education address the outcome of the object development as it is materialised in student teachers' exam papers and in formal evaluations of student teachers' classroom practices. In this respect, quality is described in terms of the graded evaluation of academic quality (grades A-F) or standard-based evaluation of practice (passed / not passed). Such applications of quality evaluation are included in ProTed through the projects that provide student teachers with knowledge and skills to be documented in exams and evaluations. From a design perspective, such quality aspects may be understood as materialised outcomes of the object 
development taking place through the interactions between the teaching and learning parts of the design (frame 3). In the digital exam described previously, such quality aspects may be identified in the student teachers' exam papers in terms of the degree to which and ways in which knowledge integration becomes visible (frame 5).

Frames 4 and 6: While one particular element of the object, namely integration, is exaggerated in the outcome of the digital exam, a quality evaluation of this element must consider its relationship to other elements of the object of a teacher education design, for instance how partnership cooperation and organisation as well as development and participation contribute to the students' competence development (frame 4 and frame 6).

Frames I and II: Moreover, as shown in a previous study (Vestøl, 2015), performative and transformative aspects of quality are highly relevant to student teachers' learning and competence development (frame II). These quality aspects will be relevant for the evaluation of how the design contributes to a constructive balance and relationship between the academic and practical aspects of competence development (frame I).

Performative quality is particularly applicable when academic knowledge and practical knowledge merge in the seminary work of teacher educators and student teachers and when student teachers develop their internship classroom practice. Of particular interest here is how the use of digital video cases and recordings in ProTed projects may facilitate boundary crossings between the academic and practical realms of teacher education and thus provide a basis for the development of integrative quality criteria and evaluation procedures.

Transformative quality relates to the academic development of critical reflection among staff and student teachers as well as to the practice-related application of knowledge in teaching and to the student teachers' personal development in response to internship challenges. In ProTed projects, there is a particular focus on the transformative aspects related to knowledge application. These quality aspects emerge to some extent in the student teachers' exams such as the digital case exam where the student teachers discuss a classroom case in light of pedagogical theory or the $R \& D$ exams where student teachers investigate their own teaching practice based on evaluations from their pupils. However, the transformative quality only becomes visible in a fuller sense when the student teachers encounter the challenges of transforming their scientific knowledge and their personal skills into proper responses to the needs of the pupils in the classroom.

As the performative and transformative aspects of quality address not only materialised outcomes but also the ways in which these qualities are developed and processed, they opt for a more holistic approach to quality evaluation than what is normally found in the criteria used for grading exams. Drawing on the three aspects of integration introduced previously (organisation, process and substance), one may say that exam papers give access to the substance aspect of 
the knowledge integration that is developed and to an assessment of quality related to this aspect. However, a quality evaluation of the organisation and process aspects will have to be addressed in other ways, and the quality evaluation of the full interaction between these aspects opts for meta-level approaches and procedures.

An important question is how the evaluation of performative and transformative aspects is addressed through the use of quality indicators. Traditionally, data such as aggregated exam results play a major role as quantitative quality indicators in higher education. While such scales of graded marks are easily translated into indicators, performative and transformative aspects of quality are harder to render in this way.

The digital exam described previously in this article may serve as an example. In this exam, the substance aspect of knowledge integration is addressed explicitly in the criteria and instructions for the digital exam and is visible in the student teachers' texts produced for this exam along with the outcome of transformation in terms of academic critical reflection. However, the performative and transformative processes related to the practical application of knowledge are less clearly displayed. To evaluate the process aspect of integration and transformation in such an exam, it might be necessary to produce material data that describe the knowledge development taking place before and during the exam, for instance in the form of logs or self-reflection notes. Evaluations of the organisational aspects of integration might need similar measures to be taken.

A particular challenge is the quality evaluation of application and transformation taking place when academic knowledge is integrated with the practical knowledge of classrooms and schools. Traditionally, such quality evaluation is a standard-based (passed / not passed) verdict based on supervisor and sensor reports from the internship practice. The digital exam and R\&D exams included in ProTed to some extent promote a knowledge integration that explores the transitions between the academic and practical realms. The use of video based supervision may provide further access to sources for the evaluation of performative and transformative quality.

Optimally, quality evaluation would include all elements and dimensions of a teacher education design. Given the complexity of the design and the range of quality aspects, it is necessary to define a selective scope. While ProTed so far has emphasised transformative aspects of knowledge integration, this focus will have to be critically examined in light of contributions from national and international research.

\section{Concluding reflections}


Drawing on the developmental work of ProTed, this article presents a notion of educational design based in sociocultural activity theory and action research. With a particular focus on knowledge integration (Figure 2), this design perspective emphasises the interaction between teaching design and learning design (Figure 1). Moreover, the article describes how evaluations of educational designs involve several aspects of quality and puts particular emphasis on performative and transformative aspects of quality (Figure 3).

Through the presentation of design elements and related quality aspects, this article tries to clarify the understanding of centrally important concepts for development and qualification of teacher education. The article contributes to a theoretically and empirically informed understanding of the concepts 'design' and 'integration'. It focuses on the interaction between teaching design and learning design as two mutually interacting elements emphasising how the student teachers contribute to their competence development by transforming the object of teaching into an object of learning. Another contribution is the understanding of knowledge integration as a nucleus of competence development within teacher education design. Still another contribution is to point out how the dynamic and interactive understanding of teacher education design opts for an approach to quality evaluations that includes the performative and transformative aspects.

While the understanding of design, integration and quality presented in this article has been developed in a Norwegian context, international research has focused on coherence as a quality aspect of design of teacher education (Buchmann \& Floden, 1992; Grossmann et al., 2008). From a comparative perspective, the concepts of coherence and integration show both similarities and differences. The similarities have to do with the emphasis on some unifying structures and trajectories of knowledge construction that counter the potential fragmentation of teacher education into separate knowledge elements. In addition, both concepts seem to point towards an optional balance between a certain need for unidirectional alignment and the openness towards multidirectional tensions that allow student teachers to explore even the unpredictable aspects of teaching and learning processes.

While coherence-oriented and integration-oriented notions of design both seem to include organisational as well as more substance-related aspects, it may be argued that coherence is more focused on the organisational aspects of teacher education while knowledge integration deals more with the process aspect in terms of student teachers' transforming of knowledge into competence.

As ProTed continues its work, further efforts are needed to develop and refine the framework presented in this article. Considering the international trends reported by Cochran-Smith et al. (Cochran-Smith \& Villegas, 2015; Cochran-Smith et al., 2015), the transformative perspective emphasised in the present article might possibly add to the efforts made to change a static approach to knowledge and learning in teacher education into a more dynamic one. 


\section{References}

Aamodt, P. O., Hovdhaugen, E., \& Prøitz, T. S. (2014). Utdanningskvalitet i høyere utdanning: noen empiriske eksempler [Quality in higher education: Some empirical examples]. NIFU.

Bakken, J. \& Sollid, H. (2013). Forskende lærerstudenter [Student teachers as researchers]. Paper presented at the FoU i Praksis 2013, Stjørdal/Levanger.

Bastia, T. (2000). Qualitative and Quantitative Indicators for the Monitoring and Evaluation of the ILO Gender Mainstreaming Strategy. ILO. Retrieved from https://www.escholar.manchester.ac.uk/uk-ac-man-scw:5b289

Bernstein, B. (1975). Class, Codes and Control. Volume 3. Towards a Theory of Educational Transmissions. London: Routledge.

Buchmann, M. \& Floden, R. E. (1992). Coherence, the Rebel Angel. Educational Researcher, 21(9), 4-9.

Carr, W. \& Kemmis, S. (1986). Becoming Critical. Education, Knowledge and Action Research. Philadelphia: The Falmer Press.

Cochran-Smith, M. \& Villegas, A. M. (2015). Framing Teacher Preparation Research: An Overview of the Field, Part I. Journal of Teacher Education, 66(1), 7-20.

Cochran-Smith, M., Villegas, A. M., Abrams, L., Chavez-Moreno, L., Mills, T., \& Stern, R. (2015). Critiquing Teacher Preparation Research: An Overview of the Field, Part II. Journal of Teacher Education, 66(2), 109-121.

Dahler-Larsen, P. (2013). Kvalitetens beskaffenhed og den svage tænkning [The nature of quality and the weak thinking]. In Y. Nordkvelle, T. Fossland, \& G. Netteland (Eds.), Kvalitet i fleksibel høyere utdanning - nordiske perspektiver [Quality in flexible higher education - nordic perspectives] (pp. 29-39). Trondheim: Akademika Forlag.

Daniels, H. (2001). Vygotsky and Pedagogy. London: RoutledgeFalmer.

Darling-Hammond, L. \& Hammerness, K. (2005). The Design of Teacher Education Programs. In L. Darling-Hammond \& J. Bransford (Eds.), Preparing Teachers for a Changing World (pp. 390-441). San Fransisco: Jossey-Bass.

Engeström, Y. (1987). Learning by Expanding. An Activity-Theoretical Approach to Development Research. Helsinki: Orienta Konsultit Oy.

Erstad, O. (2009). Addressing the complexity of impact - A multilevel approach towards ICT in education. In F. Scheuermann \& F. Pedró (Eds.), Assessing the effects of ICT in Education. Indicators, criteria and benchmarks for international comparisons (pp. 21-38). Luxembourg: JRC European Commission/OECD.

Grossmann, P., Hammerness, K., McDonald, M., \& Ronfeldt, M. (2008). Constructing Coherence. Structural Predictors of Perception of Coherence in NYC Teacher Education Programs. Journal of Teacher Education, 59(4), 273-287.

Hammerness, K. (2006). From Coherence in Theory to Coherence in Practice. Teacher College Record, 108(7), 1241-1265.

Hammerness, K. (2013). Examining Features of Teacher Education in Norway. Scandinavian Journal of Educational Research, 57(4), 400-419.

Harvey, L. \& Green, D. (1993). Defining Quality. Assessment \& Evaluation in Higher Education, 18(1), 9-34. doi: http://dx.doi.org/10.1080/0260293930180102

Hauge, T. E. (2014). Uptake and use of technology: bridging design for teaching and learning. Technology, Pedagogy and Education, 23(3), 311-323. doi: http://dx.doi.org/10.1080/1475939X.2014.942750

Hauge, T. E., Lund, A., \& Vestøl, J. M. (2007). Undervisning i endring: IKT, aktivitet, design [Education in change: ICT, activity, design]. Oslo: Abstrakt. 
KD. (2010). Forskrift om rammeplan for grunnskolelcererutdanningene for 1.-7. trinn og 5.10. trinn [National Curriculum Regulations: Teacher Education for Primary and Lower Secondary School]. Retrieved from https://www.regjeringen.no/no/dokumenter/forskrift-om-rammeplan-forgrunnskolelar/id594357/

KD. (2013). Forskrift om rammeplan for lektorutdanning for trinn 8-13 [National Curriculum Regulations: Teacher Education for Secondary School]. Retrieved from http://www.regjeringen.no/upload/KD/Vedlegg/Rammeplanen/lektorutdanning.pdf

Kikis, K., Scheuermann, F., \& Villalba, E. (2009). A framework for understanding and evaluating the impact of information and communication technologies in education. In F. Scheuermann \& F. Pedró (Eds.), Assessing the effects of ICT in Education. Indicators, criteria and benchmarks for international comparisons (pp. 69-81). Luxembourg: JRC European Commission/OECD.

Lund, A. \& Hauge, T. E. (2011). Designs for Teaching and Learning in Technology-Rich Learning Environments. Nordic Journal of Digital Literacy, 6(4), 258-272.

Pelgrum, W. (2009). Monitoring in Education: an overview. In F. Scheuermann \& F. Pedró (Eds.), Assessing the effects of ICT in Education. Indicators, criteria and benchmarks for international comparisons (pp. 41-59). Luxemboug: JRC European Commission/OECD.

Postholm, M. B. \& Jacobsen, D. I. (2011). Læreren med forskerblikk: innføring i vitenskapelig metode for leererstudenter [The teacher as researcher. Introduction to research methods for student teachers]. Kristiansand: Høyskoleforlaget.

ProTed. (2014). FoU-basert utdanning og relasjonen til utdanningskvalitet i de integrerte lærerutdanningene. Rapport [R\&D based education and quality in integrated teacher educations. Report]. UiO, UiT. Retrieved from http://www.uv.uio.no/proted/aktuelt/publikasjoner/artikler/FoUrapport\%20ProTed.pdf

ProTed. (2015). ProTed - Centre for Professional Learning in Teacher Education. Retrieved from http://www.uv.uio.no/proted/english/

Stensaker, B. (2013). Politikk, praksis og nyere perspektiver: kvalitet i nordisk høyere utdanning [Politics, practice and new perspectives: quality in Nordic higher education]. In Y. Nordkvelle, T. Fossland, \& G. Netteland (Eds.), Kvalitet i fleksibel høyere utdanning - nordiske perspektiver [Quality in flexible higher education nordic perspectives] (pp. 41-52). Trondheim: Akademika Forlag.

Tiller, T. (2006). Aksjonslæring - forskende partnerskap i skolen. Motoren i det nye læringsløftet [Action learning - school research partnership]. Kristiansand: Høyskoleforlaget.

Vestøl, J. M. (2014). Kunnskapsintegrasjon og profesjonsutvikling i lektorutdanningen [Knowledge integration and professional development in teacher education]. In E. Elstad \& K. Helstad (Eds.), Profesjonsutvikling i skolen [Professional development in school] (pp. 114-130). Oslo: Universitetsforlaget.

Vestøl, J. M. (2015). Hva er kvalitet i lærerutdanning? [Quality in teacher education]. In U. Rindal, A. Lund, \& R. Jakhelln (Eds.), Veier til fremragende læererutdanning [Roads to excellent teacher education] (pp. 202-210). Oslo: Universitetsforlaget.

Vestøl, J. M., Jakhelln, R., \& Lund, A. (2015). Design av lærerutdanning [Designing teacher education]. In U. Rindal, A. Lund, \& R. Jakhelln (Eds.), Veier til fremragende lcererutdanning [Roads to excellent teacher education] (pp. 211-220). Oslo: Universitetsforlaget.

Vygotsky, L. S. (1978). Mind in Society. The Development of Higher Psychological Processes (Ed. by Michael Cole et. al.) Cambridge: Harvard University Press. 
Wittek, L. \& Kvernbekk, T. (2011). On the Problems of Asking for a Definition of Quality in Education. Scandinavian Journal of Educational Research, 55(6), 671-684. doi: http://dx.doi.org/10.1080/00313831.2011.594618 